
\title{
СОВЕРШЕНСТВОВАНИЕ МЕХАНИЗМА ОРГАНИЗАЦИИ И ФУНКЦИОНИРОВАНИЯ ИСПОЛНИТЕЛЬНОЙ ВЛАСТИ В РОССИИ
}

\section{IMPROVING THE MECHANISM OF ORGANIZATION AND FUNCTIONING OF THE EXECUTIVE POWER IN RUSSIA}

Ya. Vasileva

Summary: One of the leading factors of successful socio-economic development of the country is the quality of public administration. Modern market relations place higher demands on the organization and functioning of the Executive power. A successful state is not only a welloptimized economic policy, but also a well-built public administration system that meets the specifics and scale of the country, is receptive to advanced technological and communication solutions, and meets the needs of society. The article examines the process of modernization of public administration in Russia from the beginning of the 90 s to the present.

Keywords: administrative reform, public administration.
Васильева Яна Валерьевна

К.ю.н., доцент, Северо-Западного институт (филиал) Университет имени О.Е. Кутафина (МГЮА), г. Вологда yana.vasileva@list.ru

Аннотация: Одним из ведущих факторов успешного социально-экономического развития страны является качество государственного управления. Современные рыночные отношения предъявляют более высокие требования к организации и функционированию исполнительной власти. Успешное государство - это не только правильно оптимизированная экономическая политика, но и правильно выстроенная система государственного управления, соответствующая специфике и масштабам страны, восприимчивая к прогрессивным технологическим и коммуникационным решениям, отвечающая потребностям общества. В статье рассматривается процесс м0дернизации государственного управления в России с начала 90-х годов по настоящее время.

Ключевые слова: административная реформа, государственное управление.
$\Pi$ о сложившейся практике модернизация государственного управления разбивалась на несколько ключевых этапов: административная реформа, реформа государственной службы, электронное правительство, бюджетная реформа. Реализация указанных реформ показала их взаимопересечение и отсутствие необходимости разделения на отдельные частные реформы. Объектом реформирования стал государственный сектор со всеми его составляющими - государственная служба, финансы, система управления, информационные ресурсы.

Реформирование государственного управления включает в себя изменение системы и структуры субъектов и объектов управления, перераспределение их полномочий, устранение дублирования и ликвидация излишних функций, совершенствование административно-правового статуса, формирование эффективных механизмов реализации их полномочий и функций. Соответственно, административная реформа представляет комплексное развитие системы государственного управления в целях обеспечения социально-экономического развития страны и роста качества жизни населения.

Административная реформа имеет длительную и поучительную историю, и не стоит связывать ее только с нашим временем [1]. «Административная реформа осуществляется постоянно с тех пор, как начался процесс управления государством, и подобное реформирование никогда не прекратится» [2]. В России указанная реформа ограничивается определенными временными периодами, отличающимися качественным своеобразием решаемых проблем и целями реформирования государственного управления. Основное назначение реформы заключается в повышении эффективности государственной власти, всех органов государственного управления, органов исполнительной власти, всех государственных служащих и чиновников [3].

Фундамент административной реформы в России (если отсчет времени вести с 1985 года) заложен более тридцати лет назад в эпоху перестройки - масштабного явления в политической, экономической и общественной жизни государства.

Так, первый этап административной реформы характеризовался конфликтом между системой государственного управления, основанной на единстве власти в централизованном унитарном государстве, и принципом разделения властей, федеративном устройстве государства на основе договора между всеми субъектами Российской Федерации. На этом этапе административные изменения осуществлялись бессистемно, шла острая борьба между различными социально-политическими силами за суверенитет России под флагом новых идеологических ценностей и выдвижением проекта экономической реформы страны на рыночной основе [4]. 
В указанный период не существовало разумной и обоснованной системы государственного реформирования, осуществлялись стремительные изменения в структуре государственного аппарата, что обусловило внутренне несогласованную систему государственного управления, усугубило путаницу и разупорядочение общественной жизни в целом. Завершение начального этапа реформы связано с глубоким политическим кризисом, проявившимся в противостоянии законодательной и исполнительной ветвей власти и необходимости принятия нового основного закона государства.

Второй этап (с 1993 по 1999 годы) административной реформы следует определить как процесс формирования правовой базы для демократического государственного управления.

Предпосылки дальнейшего реформирования содержались в Послании Президента Б.Н. Ельцина Федеральному Собранию «Об укреплении Российского государства» и принятых двух базовых для административно-политического реформирования государства законах: «Об основах государственной службы Российской Федерации» и «Об общих принципах организации местного самоуправления в Российской Федерации». В сентябре 1996 года главе государства была представлена аналитическая записка «О проблеме слабой управляемости государственными процессами», основная идея, которой, посвящена подготовке концепции нового правового порядка в государственном управлении. Центральные положения указанной записки были воспроизведены 6 марта 1997 года в Послании Президента.

Впоследствии рабочие группы экспертов разработали 12 вариантов концепции административной реформы. В концепциях подвергнуты анализу системные недостатки государственной службы и определены ключевые стороны реформы - повысить профессионализм государственной службы и эффективность взаимодействия органов исполнительной власти и гражданского общества. В марте 1998 года обсуждение проекта концепции административной реформы состоялось в Администрации Президента России. Участники совещания высказали убеждение, что до 2000 года к ее практической реализации преступать нецелесообразно.

В дальнейшем проблемы разработки направлений административной реформы сосредоточились в Центре стратегических разработок, представившем новую Концепцию государственного строительства, провозгласившую принцип «merit system» (системы заслуг и достоинств) в качестве центрального принципа построения обновленной госслужбы. Кроме того, в Концепции констатировались несогласованность власти и общества, несоответствие системы, структуры и функционирования структур исполнительной власти основам консти- туционного строя России, повторение исполнительным аппаратом советской системы управления. В 2000 году реализация проекта новой Концепции была заморожена, административная реформа вновь не состоялась.

Анализ неудач попыток проведения административной реформы и ее составной части - реформы государственной службы - показывает, что главной причиной, по которой не удалось сдвинуть с места «колесо реформ», оказалось отсутствие реального заказчика и движущих сил реформ. Российское общество так и не выступило этим главным заказчиком. В это время только у некоторой части населения начинало формироваться понимание того, что чиновник может и должен быть подотчетен обществу, а его работу можно и должно сделать полезной и эффективной. Оказались не востребованными и не задействованными такие основополагающие принципы взаимодействия граждан и государственных служащих, как прозрачность деятельности и постоянная отчетность, участие граждан в принятии решений, которые должны выступать, с одной стороны, формой общественного контроля, с другой - основой для наступления возможных санкций и поощрений, мотивирования и направления деятельности чиновников [5].

Третий этап административной реформы связан с избранием нового Президента РФ В.В. Путина. В целях реализации положений Послания Президента Российской Федерации Федеральному Собранию Российской Федерации на 2003 год, касающихся проведения административной реформы, направленной на повышение эффективности деятельности системы федеральных органов исполнительной власти и создание благоприятных условий для реализации субъектами предпринимательства своих прав и интересов, были определены следующие приоритетные направления реформы на 2003 - 2004 годы [6]:

- ограничить вмешательство органов публичной власти в экономическую (хозяйственную) деятельность субъектов предпринимательства, исключить избыточное государственное регулирование;

- исключить одинаковые функции и полномочия у разных федеральных органов исполнительной власти;

- в экономической сфере развить систему саморегулируемых организаций;

- разделить между органами исполнительной власти функции по регулированию экономической деятельности, контролю и надзору, управлению государственным имуществом и предоставлению государственных услуг;

- завершить процесс разграничения полномочий между федеральными и региональными органами исполнительной власти, оптимизировать деятельность территориальных органов федеральных органов исполнительной власти. 
Для обеспечения реализации указанных приоритетных направлений административной реформы принято решение о создании Правительственной Комиссии. Положение, утвержденное Постановлением Правительства РФ [7], определило комиссию координационным органом, с возложением на нее следующих полномочий: организация подготовки и осуществление анализа предложений по вопросам ограничения вмешательства государства в экономическую деятельность субъектов предпринимательства и прекращения избыточного государственного регулирования, применения механизма оценки эффективности деятельности федеральных органов исполнительной власти, органов исполнительной власти субъектов Российской Федерации, а также руководителей указанных органов, реформирования и развития системы государственной службы, совершенствования системы государственного управления; рассмотрение отчетов об оценке фактического воздействия нормативных правовых актов и заключения об оценке фактического воздействия нормативных правовых актов и другое. Для реализации задач и функций Правительственной комиссии были созданы рабочие группы по вопросам оптимизации структуры и функций подведомственных федеральным органам исполнительной власти федеральных государственных учреждений, федеральных государственных унитарных предприятий и федеральных казенных предприятий, действующих в соответствующих сферах государственного регулирования [8].

Важнейшим решением этого этапа административной реформы стала реорганизация федерального управленческого аппарата, осуществляемая в соответствии с Указом Президента [9], выраженная в установлении трехуровневой системе управления: федеральное министерство, федеральная служба, федеральное агентство. Кроме того, в административном законодательстве до 2004 г. не существовало официально установленной типологии функций органов исполнительной власти. В результате реализации Указа № 314 и Указа № 649 [10] была принята следующая типология функций органов исполнительной власти: 1) функции по принятию нормативных правовых актов; 2) функции по контролю и надзору; 3) функции по управлению государственным имуществом; 4) функции по оказанию государственных услуг. Было признано, что эти функции являются «неотъемлемо государственными» и осуществляются федеральными органами исполнительной власти. Впервые реформа обеспечила реализацию важнейшего управленческого принципа, когда бесконечная реорганизация государственного аппарата может быть заменена давно апробированным принципом - сначала функции органа исполнительной власти, а потом его структура и штаты. Это позволит создать эффективный и оптимальный аппарат управления, не позволит до бесконечности разрастаться штатам и появляться избыточным и несвойственным функциям.
В целях совершенствования государственного управления и правосудия, оптимизации структуры и упорядочения функций федеральных органов исполнительной власти Указом Президента [11] летом 2004 года создана Комиссия при Президенте Российской Федерации по вопросам совершенствования государственного управления и правосудия. При Комиссии созданы межведомственные рабочие группы по обеспечению мероприятий, связанных с реформированием и развитием государственной службы и совершенствованием законодательства Российской Федерации о судебной системе; по вопросам федеративных отношений и местного самоуправления; по вопросам системы и структуры федеральных органов исполнительной власти.

Таким образом, к 2005 году были созданы требуемые условия для последующего комплексного усовершенствования системы государственного управления, поскольку стадии практической реализации достигла лишь относительно небольшая часть мероприятий административной реформы.

Стратегические направления четвертого этапа административной реформы определились 25 октября 2005 года, когда Правительство РФ одобрило Концепцию административной реформы в Российской Федерации на 2006 - 2010 годы [12] - важнейший в современной истории нормативный правовой акт, направленный на проведение реформы государственного управления. Цели реформы были обозначены следующие:

- повысить качество и доступность государственных услуг;

- ограничить вмешательство органов публичной власти в экономическую (хозяйственную) деятельность субъектов предпринимательства, исключить избыточное государственное регулирование;

- повысить эффективность деятельности органов исполнительной власти.

Для достижения целей сформулированы следующие задачи:

- внедрить в органах исполнительной власти принципов и процедур управления по результатам;

- разработать и внедрить стандарты предоставления государственных услуг, а также административных регламентов в органах исполнительной власти;

- оптимизировать деятельность органов исполнительной власти и ввести механизмы противодействия коррупции в сферах их функционирования;

- повысить уровень взаимодействия органов исполнительной власти и гражданского общества, а также повысить открытость деятельности органов публичной власти;

- модернизировать систему информационного обе- 
спечения органов государственного управления;

- сформировать необходимый уровень организационного, информационного, ресурсного и кадрового обеспечения административной реформы, усовершенствовать механизмы распространения успешного опыта государственного управления.

В приложении к Концепции были утверждены не просто показатели достижения целей административной реформы, но и установлены сроки их достижения:

1. Оценка гражданами деятельности органов исполнительной власти по оказанию государственных услуг. Предполагалось, что в результате проведения административной реформы степень удовлетворенности граждан качеством и доступностью государственных услуг повысится к 2008 году до 50\% и к 2010 году - не менее чем до 70\%.

2. Уровень издержек бизнеса на преодоление административных барьеров. По данным научных исследований размер издержек бизнеса на преодоление административных барьеров в 2004 году составил в среднем 8,5\% прибыли предприятия. В качестве целевого показателя реализации мероприятий административной реформы определено снижение к 2008 году до 5 процентов, к 2010 году - до 3 процентов.

3. Место Российской Федерации в международных рейтингах показателей качества государственного управления. В 2004 году в международный рейтинг входило 209 стран. Процентный ранг России по эффективности государственного управления в 2004 году равнялся 48,1 единицы (из 100 возможных), по качеству государственного регулирования - 30,5 единицы (из 100 возможных). В качестве целевых ориентиров по данным показателям предполагалось к 2008 году достичь значение показателя эффективности государственного управления 55 единиц, эффективности государственного регулирования - 60 единиц, а в 2010 году - не ниже 70 единиц по каждому из показателей.

В 2008 году стало очевидно, что эти и другие показатели не достигнуты, цели и задачи административной реформы не выполнены. И вместо того, чтобы искать причины, сделать соответствующие выводы, законодатель идет по наиболее простому пути - он продлевает действие Концепции на два года и принимает новую редакцию, в которой к задачам административной реформы добавляет необходимость создания единой вертикально интегрированной автоматизированной системы мониторинга результативности деятельности органов государственной власти и органов местного самоуправления по достижению важнейших показателей социально-экономического развития Российской Федерации и исполнения ими своих полномочий (ГАС «Управление»); создание многофункциональных центров предоставления государственных и муниципальных услуг; организацию предоставления государственных услуг в электронной форме.

Поскольку в 2010 году истек срок реализации Концепции административной реформы в Российской Федерации на 2006-2010 годы, проведенная работа оказалась недостаточной для обеспечения эффективности государственного управления, следствием Правительством РФ была подготовлена и утверждена Концепция снижения административных барьеров и повышения доступности государственных и муниципальных услуг на 2011-2013 годы [13], где декларировался новый комплексный подход к реформированию, в рамках которого объектом реформирования становился «государственный сектор со всеми его компонентами (государственная служба, финансы, система управления и информационные ресурсы).

В целях дальнейшего совершенствования системы государственного управления 7 мая 2012 года [14] Президентом перед Правительством РФ поставлены задачи по достижению стратегических показателей: уровня удовлетворенности граждан Российской Федерации качеством предоставления государственных и муниципальных услуг; доступа к получению государственных и муниципальных услуг по принципу «одного окна»; механизма получения государственных и муниципальных услуг в электронной форме; снижения числа обращений представителей бизнес-сообщества в органы государственной власти Российской Федерации; времени ожидания в очереди при обращении заявителя в органы власти для получения государственных (муниципальных) услуг. В России создается система раскрытия информации о разрабатываемых проектах нормативных правовых актах и результатах их общественного обсуждения. Она реализуется на базе единого сайта ww.regulation. gov.ru, специально созданного для размещения федеральными органами исполнительной власти информации о подготовке проектов нормативных правовых актов и результатах их общественного обсуждения.

По настоящее время административные реформы не прекращают свою реализацию, так по законопроекту главы государства принят Кодекс административного судопроизводства Российской Федерации, 21 декабря 2016 года Президиум Совета при Президенте РФ по стратегическому развитию и приоритетным проектам утвердил паспорт приоритетной программы «Реформа контрольной и надзорной деятельности», в котором отражены основные задачи по совершенствованию системы государственного контроля и сокращению избыточного давления на бизнес, поставленные Президентом РФ. Центральными направлениями совершенствования системы государственного управления, по которым в 
настоящее время ведется систематическая работа, являются: снижение избыточного государственного регулирования, повышение качества государственных услуг, повышение эффективности органов власти, повышение информационной открытости. На официальном портале административной реформы Министерства экономического развития и на портале «Совершенствование государственного управления» представлены итоги деятельности по каждому вышеназванному направлению.

Реформирование системы государственного управ- ления в России - важнейшее условие ускорения социально-экономического развития страны. За годы административной реформы были разработаны и внедрены основные стандарты государственных услуг и административных регламентов, программы противодействия коррупции в органах исполнительной власти, ликвидированы их избыточные функции, значительно оптимизирована деятельность по осуществлению функций контроля и надзора, созданы многофункциональные центры предоставления государственных и муниципальных услуг.

\section{ЛИТЕРАТУРА}

1. Старостин С.А. Административные реформы в период Российской империи // Вестник Университета имени 0.Е. Кутафина (МГЮА). 2018. № 1 (41). С. $39-47$.

2. Россинский Б.В. Реализация концепций административной реформы // Вестник Университета имени 0.Е. Кутафина (МГЮА). 2018. № 1 (41). С. 31.

3. Старостин С.А. 0 некоторых проблемах реализации административной реформы в Российской Федерации и путях их решения // Lex Russica. 2008. T. LXVII. № 4. C. 875-884.

4. Станкевич Л.Т., Горбатова Н.В. Административная реформа России как процесс формирования диалога государственной власти и общества // Научнопрактический журнал Северо-Западной академии государственной службы. 2005. № 3. С. 197-211.

5. Васильев М.Е. Административная реформа в новейшей истории государственного строительства России // Государственное и муниципальное управление. Ученые записки СКАГС. 2005. № 3-4. С. 126-130.

6. Указ Президента РФ от 23.07.2003 № 824 «0 мерах по проведению административной реформы в 2003 - 2004 годах» // Собрание законодательства РФ. 28.07.2003. № 30, ст. 3046.

7. Постановлением Правительства РФ от 31.07.2003 № 451 (ред. от 21.11.2018) «0 Правительственной комиссии по проведению административной реформы» // Собрание законодательства РФ. 04.08.2003. № 31. ст. 3150.

8. Распоряжение Правительства РФ от 21 мая 2004 г. № 682-р (ред. 29.11.2007) «0 создании рабочих групп при Правительственной комиссии по проведению административной реформы» // Собрание законодательства. 31.05.2004. № 22. ст. 2192. (утратило силу).

9. Указ Президента РФ от 09.03.2004 N 314 (ред. от 28.09.2017) «0 системе и структуре федеральных органов исполнительной власти» // Собрание законодательства РФ. № 11. 15.03.2004. ст. 945.

10. Указ Президента РФ от 20.05.2004 № 649 (ред. от 25.08.2010, с изм. от 30.04.2016) «Вопросы структуры федеральных органов исполнительной власти» // Собрание законодательства РФ. 24.05.2004. № 21. ст. 2023.

11. Указ Президента РФ от 16.07.2004 № 910 (ред. от 10.03.2007) «0 мерах по совершенствованию государственного управления» // Собрание законодательства РФ. 19.07.2004. № 29. ст. 3019. (утратил силу).

12. Распоряжение Правительства РФ от 25.10.2005 № 1789-р (ред. от 10.03.2009) «0 Концепции административной реформы в Российской Федерации в 2006 - 2010 годах» // Собрание законодательства РФ. 14.11.2005. № 46. ст. 4720.

13. Распоряжение Правительства РФ от 10.06.2011 № 1021-р (ред. от 28.08.2012) «06 утверждении Концепции снижения административных барьеров и повышения доступности государственных и муниципальных услуг на 2011 - 2013 годы и Плана мероприятий по реализации указанной Концепции // Собрание законодательства РФ. 27.06.2011. № 26. ст. 3826.

14. Указ Президента РФ от 07.05.2012 № 601 «06 основных направлениях совершенствования системы государственного управления» // Собрание законодательства РФ. 07.05.2012. № 19. ст. 2338.

(с) Васильева Яна Валерьевна (yana.vasileva@list.ru).

Журнал «Современная наука: актуальные проблемы теории и практики» 